\title{
Studies on raising and preparation of planting stock of three indigenous forest timber species in Nigeria
}

\author{
J.E. EHIAGBONARE ${ }^{1 *}$ and H.I. ONYIBE ${ }^{2}$ \\ ${ }^{1}$ Department of Biological sciences, Igbinedion University, Okada, Edo State, Nigeria. \\ ${ }^{2}$ Department of Botany, Ambrose Alli University, Ekpoma, Edo State, Nigeria. \\ *Corresponding author, E-mail: drehiagbonare@yahoo.com
}

\begin{abstract}
Seed germination studies, seedling growth, planting stock preparation and field trial at planting espacement of $3 \mathrm{~m} \times 3 \mathrm{~m}$ were evaluated in the study. Soaking seeds in tap water for ten days with daily replacement of water yielded $100 \%$ seed germination for A. africana, $100 \%$ for A. boonei and $90 \%$ for A. lebbeck respectively in light condition. These values were better than those obtained in the control and dark condition. Growth values observed in forest topsoil were significantly different from those from river sand. From Forest Topsoil the total plant heights were $98 \pm 16.33 \mathrm{~cm}$ for A. africana, $41 \pm 6.83 \mathrm{~cm}$ for A. lebbeck and $70 \pm 11.66 \mathrm{~cm}$ for $A$. boone $i$ while from the river sand, A. Africana had $36 \pm 6.0 \mathrm{~cm}$, A. lebbeck had $26.3 \pm$ $4.38 \mathrm{~cm}$ and A. boonei had $25.6 \pm 4.27 \mathrm{~cm}$. The field trial showed that there is prospect of successful domestication of these species using stumps or seedlings as planting stock. Significant difference was not observed in the trial. The only observed advantage is that more stumps can be transported than the seedlings. For quality planting stock production, soaking the seeds of the species under study for 10 days with daily replacement of water, forest topsoil as seedling growth medium, stumps and seedlings as planting stock are recommended.
\end{abstract}

(C) 2008 International Formulae Group. All rights reserved.

Keyword: Afzelia africana, Albizia lebbec, Alstonia boonei,Planting stock, Agroforestry.

\section{INTRODUCTION}

Afzelia Africana (Leguminosae),

Albizia lebbeck L (Mimosaceae) and Alstonia boonei De Wild (Apocynaceae) have uses in Ethno Medicine, health care delivery system and timber industries in Nigeria. Afzelia africana is known in Bini, Hausa and Fulani languages as "arinyan", "kawo" and "gayohi", respectively. Phytochemical constituents of the plant are alkaloids and tannins (Gill, 1992). The leaf, stem bark, root and pod are the main parts used in ethno medicine. The decoction of the leaves and Xylopia fruits are given in general oedema. The root decoction in hot drink or local gin is taken for the treatment of stomach disorders, gonorrhorea and hernia. The pods are used for veterinary medicine. Local names of Albizia lebbeck are "eshegeshege" in Bini language and "igbagbo" in Yoruba. Tannins and alkaloids are the main phytochemical constituents of the plant. Night blindness is treated with the juice from the leaves. Dysentry, gonorrhoea and diarrhea are also treated with decoctions form this plant. Alstonia boonei is mostly found in wet areas of Southern Nigeria. It is locally called "ukhu" in Binin, "awun" in Yoruba and "eghu" in Igbo land. Alkaloids, inulin, tannins, echitamine, echimidine and saponins are the phytochemical constituents of the species (Gill, 1992). This plant has diverse ethno uses. It is used for treatment of dysentery, rheumatism, swollen foot, and as antiperiodic, among others (Gill, 1992).

Natural plants have been considered as valuable sources of medicinal agents with 
proven potential of treating infectious diseases and with lesser side effects compared to the synthetic drug agents (Shittu et al., 2006). Several studies have been conducted in the past three decades that focus on the antimicrobial properties of plants (Kivanc and Agul, 1986, Dorman and Deans, 2000). Apart form the medicinal values of the species under study, they play a key role in industrial growth in Nigeria. They form the basis of raw materials for wood-based industries. Interest in medicinal plants as a re-emerging healthaid has been fuelled by the rising cost of prescription drugs and prospecting for new plant derived drugs (Hoareau and Dasilivia, 1999). Nolan and Labbe (2004) believe that infectious disease might best be met with new anti-infective agents from plants. Some plants extracts have been credited with anti bacterial properties (Kone et al., 2004).

Inspite of the usefulness of Afzelia africana, Albizia lebbeck and Alstonia boonei they are still in the wild. Their over exploitation due to their importance and the high rate of deforestation in the tropics and Nigeria in particular shows that there is the likelihood of these species's possible extinction if not domesticated and sustainably managed. The survival of Afzelia africana, Albizia lebbeck and Alstonia boonei, their availability in the right quality and quantity, their role in the support of industries and ethno medicine as raw material depends on their domestication. Furthermore these taxa cannot naturally regenerate adequately. The first step in plantation forestry is quality planting stock. This accounts for success or failure of the plantation. Evaluation of planting stock is vital to avoid failure and waste of funds for plantation forestry. The purpose of this study was to provide useful information as basis for the domestication of the indigenous taxa in Nigeria and thus aid their conservation.

\section{MATERIALS AND METHODS}

Planting materials - the seeds

These were obtained from the mother trees in dry state. The tree species were identified by a botanist and forester in the Department of Botany, Igbinedion University, Okada, Edo State, Nigeria. The dry state was an indication that the seeds were matured. The standard poly pots used were purchased locally and they contained drainage holes. The growth media used were forest topsoil obtained from the habitat of the species and white river sand. The method described by McCarthy (2005) was used in preparing planting stock.

\section{Seed viability test and drying methods}

The seeds after extraction from the fruits were tested for viability using the floation method. The seeds were steeped into a suitable container of water and stirred with a stick. After about five minutes the container was observed. The seeds that floated were discarded as non viable seeds and the ones that sank regarded as viable seeds. These were removed from the water and spread on old news print to dry under room temperature (30 $\pm 2{ }^{\circ} \mathrm{C}$ ). The seeds were regarded as dry after six days when they no longer stick together. The seeds were stored in plastic buckets in the laboratory.

\section{Seed germination experiment}

Seed germination experiment was conducted in light and dark conditions in laboratory. The seeds meant for dark conditions were wrapped with aluminum foil and kept in a dark cupboard in the laboratory. Each Petri dish contained 10 seeds replicated three times and watered as necessary. Seed germination was monitored for a period of 30 days after which there was no more germination. Germinated seeds were recorded and discarded.

\section{Seedling growth experiment}

Seedlings were grown in standard poly pots with drainage holes for a period of 36 weeks. Two sets of growth media were used. These were forest topsoil and river sand. Seedlings from germination beds at two leaf stage were transferred into the pots watered to field capacity. The poly pots were replicated three times and arranged in a randomized block design under light shade of palm leaves. At the end of the experiment (36 weeks) the following parameters were assessed. Total plant height $(\mathrm{cm})$, shoot length $(\mathrm{cm})$, root length $(\mathrm{cm})$, number of leaves, number of secondary roots and number of root hairs were determined. 
Field trial for two years - stumps and seedlings

At 9 months field trial of the species under study was conducted. A two hectare plot was marked out, 3 plots were randomly selected and pegged. Two planting stocks were prepared. Some seedlings were reduced to stumps using very sharp machete. The length of the stumps was $30 \mathrm{~cm}$ with the upper part being $3 \mathrm{~cm}$. The seedlings had some leaves removed leaving the few ones at the apex. These were planted in the field. Spot weeding was done regularly to reduce competition from weeds. At the end of the second year of planting the two planting stocks were evaluated for the number of dead stumps and seedlings, total height and diameter at breast height. The frequency occurrence of the species under study was assessed in three different locations in natural forest. The locations were tagged zones A, B, C. In each Zone, plots of $1 \mathrm{~m} \mathrm{x} 10 \mathrm{~m}$ were established. The plots were replicated three times. The four corners of the plots were marked with wooden pegs to demarcate them from the other part of the forest. The species under study were identified in each plot and the number of times each occurred was recorded. At the end of recording the species were sorted and the total number of occurrence was recorded according to species. The mean number of occurrence per plot was determined. All results obtained from the study were statistically analyzed where necessary. Analysis of variance and percentages were used.

\section{RESULTS AND DISCUSSION}

Significant differences at 5\% level were observed in response to soaking in tap water pre-sowing treatment and germination in light and dark conditions. The treatment had better results with all species than the control (Fig. 1). These species had higher percentage germination in light condition than in the dark condition. In the light condition $A$. african had $100 \%$ seed germination, $A$. lebbeck $-90 \%$ and A. boonei-100\%. These are higher values than what was obtained in the dark condition and the control (Fig 1). This is probably due to the fact that these species are light loving. From the study it is obvious that the species are photoblastic. The results of Robberts (1996) on seed soaking regimes in which he reported higher values in treatment than in the control for various seeds of various species are inconsonance with the result of this study. From the seedling growth study evidence from the results showed that significant differences exist in the performance of seedlings in the growth media (Table 1). Forest topsoil supported better seedling growth (Table 1). Total height growth of $98 \pm 16.33 \mathrm{~cm}$ for A. africana, $41 \pm$ $6.83 \mathrm{~cm}$ for $A$. lebbeck and $70 \pm 11.66 \mathrm{~cm}$ for A. boonei were obtained from the seedlings growing in forest topsoil respectively. The values obtained from the river sand were $36 \pm$ $6.0 \mathrm{~cm}$, A. africana, $26.3 \pm 4.38 \mathrm{~cm}$ and $A$. lebbeck and $25.6 \pm 4.27 \mathrm{~cm}$ for $A$. boonei. These values are lower than those obtained from the forest topsoil (Table 1). Other parameters are also lower in the result from the river sand (Table 1). The findings of Egharevba and Bamidel (1998) where they evaluated the growth of Chrysophyllum albidum using forest topsoil as growth medium is harmony with the findings of this study. Evidence from this aspect of the study showed that good/improved growth media are vital for the production of healthy seedlings for field planting to achieve successful forest plantation establishment.

From the filed trial there was no significant difference observed in growth parameters measured (Table 2). There was no evidence of dead stumps or seedlings. The implication of this, is that when properly handled both planting stock can be used for field planting with a good measure of success. The information from the study showed that the seeds of the three species can be germinated successfully by soaking for 10 days with daily changes of water, good seedling growth obtained by growing seedlings in forest topsoil and planting stock could be seedlings or stumps. These are recommended for raising planting stock in a tree nursery for afforestation programme. Thus this study has provided useful information for the domestication and sustainable management of these very important indigenous taxa. Evidence from the plots (Table 3) showed that a mean number of one species occurred per plot. This distribution is poor and only domestication can save these species from extinction. 
A. africana

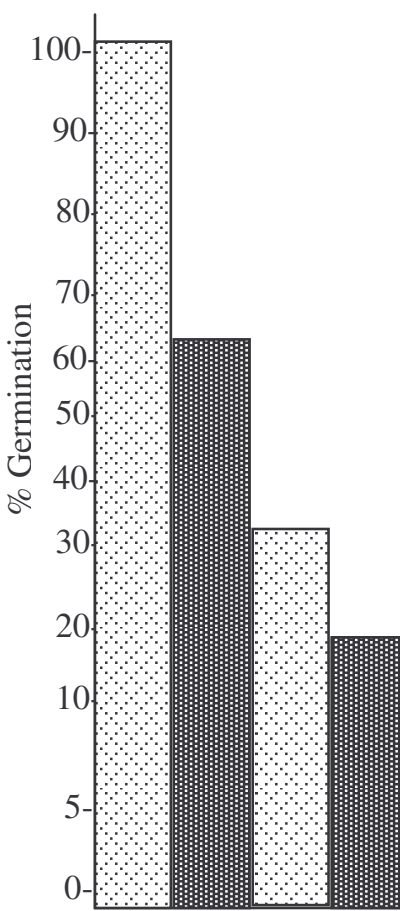

10 days Control
A. lebbeck

A. boonei

Soaking duration in days with daily changes of water

Light

Dark

Fig. 1: Effect of soaking duration on seed germination of A. africana, A. lebbeck and A. boonei.

Table 1: Growth parameters of A. africana, A. lebbeck and A. boonei. Seedlings at 36 weeks after sowing in topsoil and River sand.

\begin{tabular}{lcccccc}
\hline \multirow{3}{*}{ Parameters } & \multicolumn{5}{c}{ Growth media } \\
\cline { 2 - 7 } & \multicolumn{3}{c}{ Sorest topsoil } & \multicolumn{3}{c}{ River sand } \\
\cline { 2 - 7 } & A.a & A.1 & A.b & A.a & A.1 & A.b \\
& $98 \pm 16.33$ & $41 \pm 6.83$ & $70 \pm 11.66$ & $36 \pm 6.0$ & $26.3 \pm 4.38$ & $25.6 \pm 4.27$ \\
Total Plant height & & & & & \\
$(\mathrm{cm})$ & $68 \pm 11.33$ & $18 \pm 30$ & $33 \pm 5.50$ & $26 \pm 4.33$ & $9 \pm 1.50$ & $15.6 \pm 2.60$ \\
Shoot length (cm) & $30 \pm 5.0$ & $23 \pm 3.83$ & $27 \pm 4.50$ & $10 \pm 1.66$ & $17.3 \pm 2.88$ & $10 \pm 1.66$ \\
Root length (cm) & $20.38 \pm 33.83$ & $18 \pm 30$ & $180 \pm 30.00$ & $9 \pm 1.50$ & $8 \pm 1.33$ & $10 \pm 1.66$ \\
No. of leaves & $11 \pm 1.83$ & $53 \pm 8.83$ & $40 \pm 6.66$ & $15 \pm 2.66$ & $16 \pm 2.67$ & $25 \pm 4.16$ \\
No. of secondary roots & $266 \pm 44.33$ & $63 \pm 10.50$ & $180 \pm 30.00$ & $30 \pm 5.0$ & $24 \pm 4.00$ & $33 \pm 5.50$ \\
No. of root hairs & & & & & \\
\hline
\end{tabular}

Tabulated values are mean \pm SD of three determinations.

A.a = Afzelia africana $;$ A.1 = Albizia lebbeck $;$ A.b = Alstonia boonei 
Table 2: Field trial on A. africana, A. lebbeck and A. boonei planting stock at $3 \mathrm{~m} \mathrm{x} 3 \mathrm{~m}$ at 2 years after transplanting.

\begin{tabular}{lccc}
\hline $\begin{array}{l}\text { Planting } \\
\text { Species }\end{array}$ & \multicolumn{2}{c}{ Total Height $(\mathbf{c m})$} & $\begin{array}{c}\text { Diameter (cm) } \\
\text { Dbh 1.3m }\end{array}$ \\
\cline { 2 - 3 } & Stumps & Seedlings & \\
A. Africana & $118 \pm 24.08$ & $124 \pm 25.71$ & $6.15 \pm 1.25$ \\
A. lebbeck & $115 \pm 24.47$ & $120 \pm 24.49$ & $6.45 \pm 1.31$ \\
A. boonei & $120 \pm 24.49$ & $120 \pm 26.12$ & $7.25 \pm 1.47$ \\
\hline
\end{tabular}

Tabulated values are mean \pm SD of three determinations.

There is no significant difference in height and diameter growth of the planting stock for the field trials and no seedling death was recorded.

Table 3: Frequency distribution of Afzelia africana, Albuizia lebbeck and Alstonia boonei in natural forest.

\begin{tabular}{lllll}
\hline Zone & 1 x 10 m Plots & \multicolumn{3}{c}{ Species } \\
\cline { 3 - 5 } & & Aa & A1 & Ab \\
\hline \multirow{2}{*}{ A } & 1 & 2 & 0 & 2 \\
& 2 & 0 & 0 & 2 \\
& 3 & 1 & 1 & 0 \\
B & 1 & 2 & 4 & 2 \\
& 2 & 3 & 1 & 0 \\
& 3 & 2 & 1 & 2 \\
C & 1 & 3 & 2 & 2 \\
& 2 & 2 & 1 & 2 \\
\multirow{2}{*}{ Total $=$} & 3 & 2 & 2 & 1 \\
Mean $=\sum \mathrm{x}$ & 9 & 17 & 12 & 13 \\
\hline
\end{tabular}

Aa-Afzelia africana, A1-Albizia lebbeck, Ab-Alstonia boonei

\section{REFERENCES}

Dorman HJD, Deans SG. 2000. Antimicrobial agents from plants: Antimicrobial activity of plant volatile oils. Journal of Applied Microbial Science, 88: 308-316.

Egharevba RKA, Bamidele JF 1998. The growth responses of $\mathrm{C}$. albidum seedlings to different potting Mixures. Journal of Horticultural Science, 2: 30-36.

Gill SL. 1992. Ethnomedical Uses of Plants in Nigeria. Uniben Press: Edo State, Nigeria; 16-25.
Hoareau LE, Dasilivia J. 1999. Medicinal plants: a re-emerging health and Elect. Journal of Biotechnology, 2: 2.

Kivanc M, Agul A. 1986. Antimicrobial activities of essential oils from Turkish species and Citrus. Flavour and Fragrance: $1175-1179$.

Kone WM, Atindehou KK, Tarreaux C, Hosetettman K, Traore D, Dosso M. 2004. Traditional medicine in North Cote-d'Ivoire: Screening 50 medicinal 
plants for antibacterial activity. Ethnophamacol. Bul., 93(1): 43-49.

McCarthy R B. 2005. National School Tree Planting Project, 11 Jessie Street, Westgarth, Melnourne, Victoria 3070, pp 28-30.

Nolan LL, Labbe RG. 2004. Future of natural products from plants in the struggle with emerging diseases: case of food-borne pathogens and Leishmaniases. Journal of Herbs, Spices Med. Plants, 11: 614.
Robberts EG. 1996. Growing Trees and Shrubs from Seeds. Montana State University 59717; 1-8.

Shittu LAJ, Bankole MA, Ahmend T, Aile K, Akinsanya MA, Bankole MN, Shittu RK and Ashiru DA. 2006. Differential antimicrobial activity of the various crude leaves extracts of Sesame radiatum against some common pathogenic microorganisms. Journal of Scientific Research and Essays, 1(3): 108-111. 